
A C T A

Jacek SZLAKOWSKI

Fish biology

\title{
GROWTH OF PSETTA MAXIMA (LINNAEUS, 1758) FROM THE GULF OF POMERANIA
}

\author{
WZROST SKARPIA PSETTA MAXIMA (LINNAEUS, 1758) \\ $\mathbb{Z}$ ZATOKI POMORSKIEJ \\ Department of Biological Marine Resources, \\ Academy of Agriculture in Szczecin
}

\begin{abstract}
Growth in length and weight of Psetta maxima in consecutive years of life was determined basing on back calculation of age from the otoliths. Von Bertalanffy's equation and Szypuła?s polynomials were also used.
\end{abstract}

\section{INTRODUCTION}

Psetta maxima (L.) is a little known fish inhabiting the Baltic Sea. This is due to low abundance of this fish and low catches ( 82 tons in 1980, ICES 1982). The fish is of negligible economic importance; percentage of Psetta maxima in Polish catches of flatfishes does not exceed 2\% (Draganik and Reiman 1979).

The species is more abundant in the Gulf of Pomerania; its spawning grounds are located over the Oder Sandbank (Fesołowicz and Wiktor 1959).

The objective of the study was to determine growth rate of Psetta maxima in the Gulf of Pomerania. This problem has been never studied before.

\section{MATERIAL AND METHOD}

Materials were collected from March till Mày 1984. They originated from commercial catches of fishermen from "Certa" Cooperative in Międzywodzie. Psetta maxima represented a small by-catch in the catch of "white fishes" i.e. bream, roach, pikeperch and flounder, obtained with gill nets set in coastal waters, about 1 nautic mile from the shore, in the fishing zone E-2 (Fig. 1). 


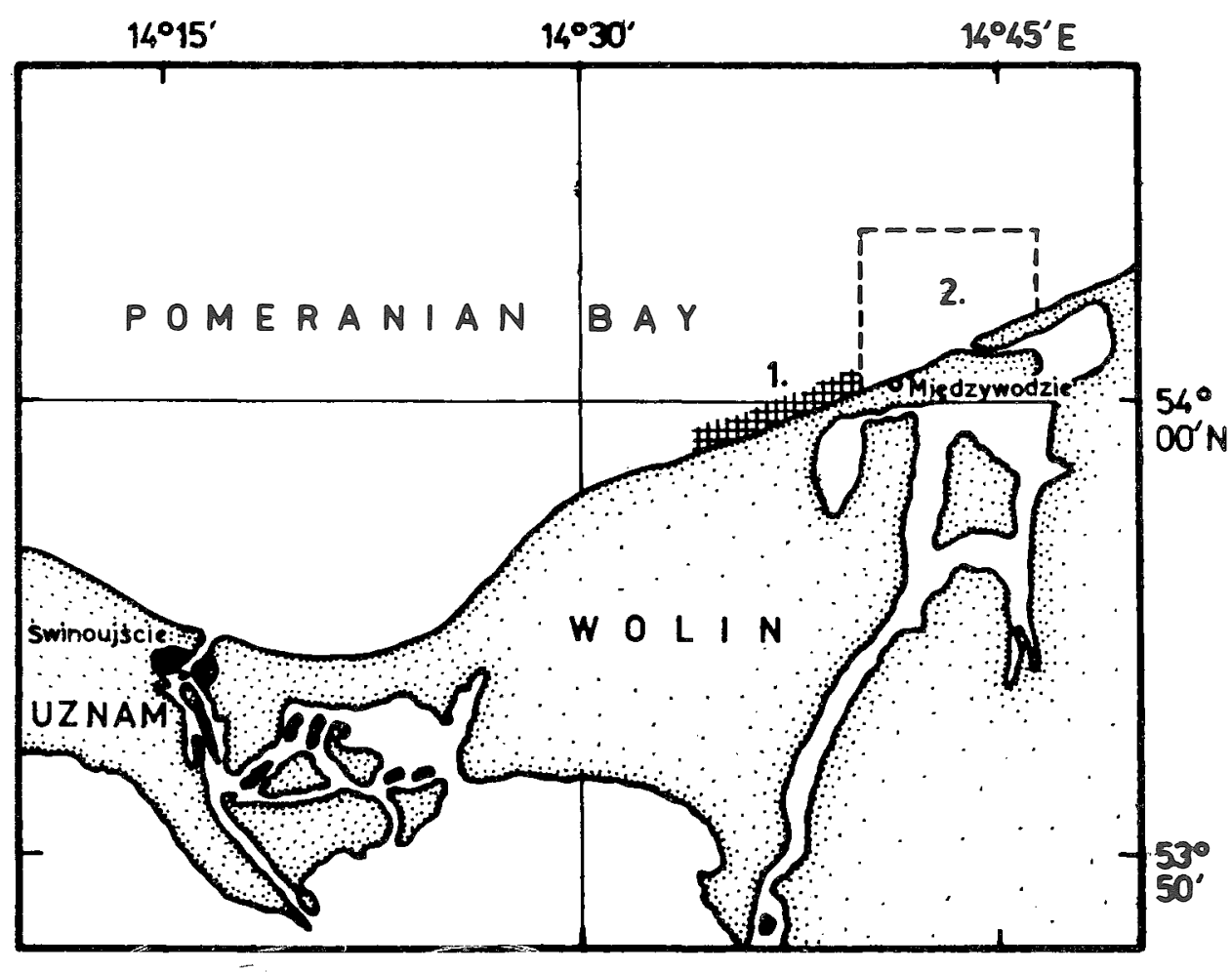

Fig. 1. Sampling areas for turbot in Pomeranian Bay.

1 - sampling sites of juvenile turbot in 1982-84;

2 - area of adult fish catches in 1984 ,

Total length of 209 fishes was measured up to $1 \mathrm{~mm} ; 174$ fishes were weighed up to $5 \mathrm{~g}$. Otoliths were collected from 159 fishes, but 155 pairs of these were used in the analysis.

Otoliths were placed in water over a dark background, viewed and measured in incident light using a Zeiss measuring microscope. Longer radius was measured in the otoliths collected from 157 fishes in 1984, and additionally in the otoliths collected in 1983 from 68 fishes at the age of $0+$. Dahl-Lea method of back calculation was used to determine the growth rate. Average length in age groups was calculated from these data using von Bertalanffy's equation and polynomials of the 2 nd order (Szypuła 1977). $\mathrm{L}_{\infty}$ parameter in von Bertalanffy's equation was obtained with linear regression used within a coordinate system $y=L_{t+1}-L_{t}$ and $x=L_{t}$ for points along the line above the inflexion point (Ricker 1983). Parameters $\mathbb{K}$ and $t_{0}$ were determined in a coordinate system $y=\ln$ 
$\left(\mathrm{L}_{\infty}-\mathrm{L}_{\mathrm{t}}\right)$ and $\mathrm{x}=\mathrm{t}$ (FAO 1981). Average age at which Psetta maxima reached $95 \% \mathrm{~L}_{\infty}$ was calculated from Taylor's equation (1962); assuming af ter Pauly (1980) the maximum age, $\mathrm{t}_{\max B}$.

To establish the relationship between weight (W) and total fish length (1.t.), the equation $W=a L^{n}$ was used. $W_{\infty}$ was obtained using $L_{\infty}$ in this equation. This is one of the parameters of a modified von Bertalanffy's equation for weight increase. Average weight in consecutive years was obtained using average length in these years. The latter were also used to obtain parameters of the polynomial of the 3rd order, modelling growth in weight (Szypuła 1977).

Parameters of all equation were obtained with the least square method,.using matrix calculus (Balicki and Bielecki 1980, Polard 1982).

\section{RESULTS}

\section{Length of the fish caught}

Length of males varied between 8 and $32 \mathrm{~cm}$, and of females between 16 and $48 \mathrm{~cm}$ (Fig. 2). 'Peaks" of the length distribution were assumed to represent modal length in age

$\Delta$
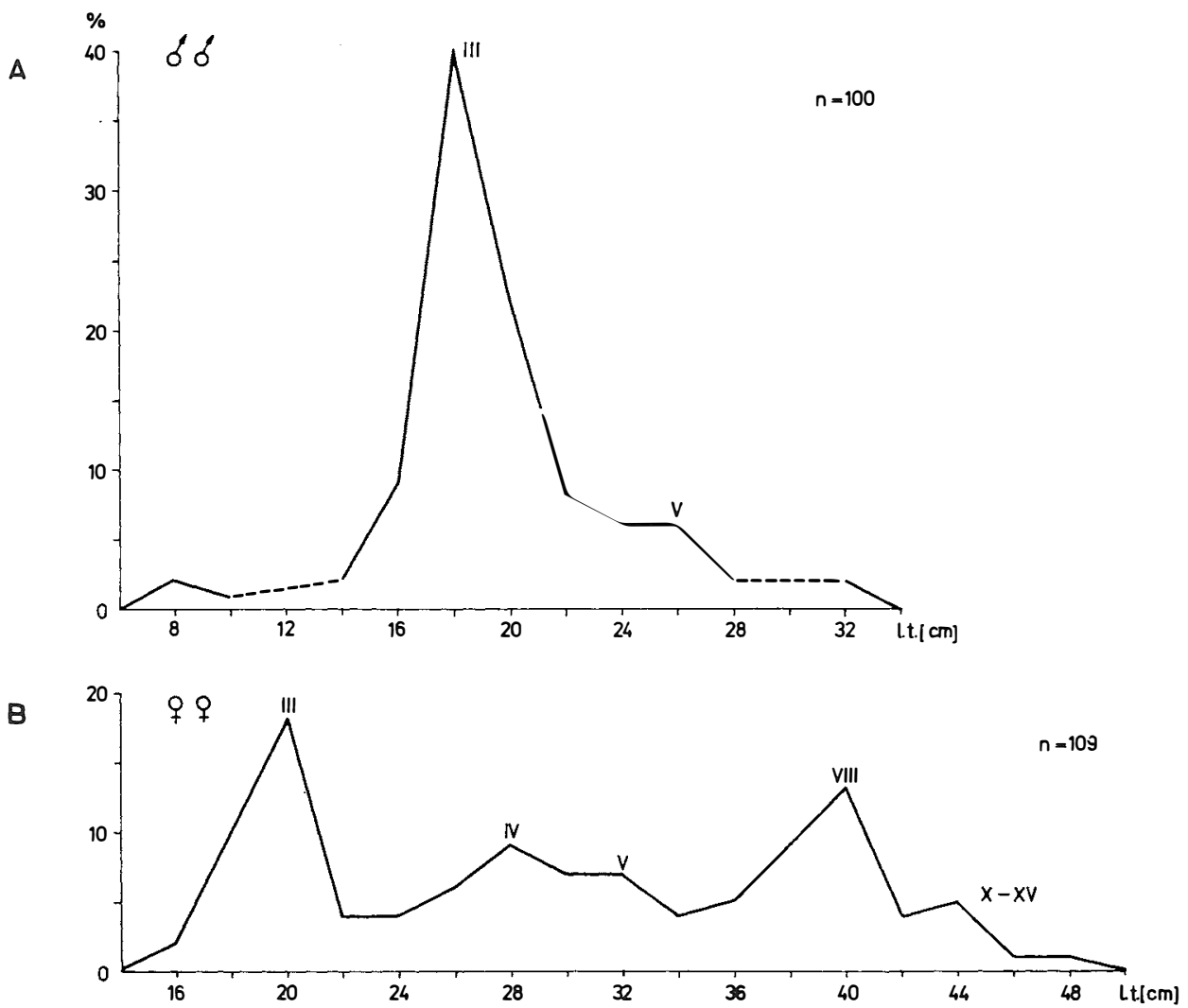

Fig. 2. Length frequency distributions of turbot caught in March - May 1984. A - males; B - females. Numerals III-XV denote age groups. 
groups. The assumption was based on direct observations as well as back calculation of age. As regards the males, fishes $18-20 \mathrm{~cm}$ were most abundant; these belonged to the age group III. A weak peak was formed by the fish $26 \mathrm{~cm}$ in length, of the age group V. The consecutive age groups were not all represented by the curve. This was due to relatively low numerosity of the samples, and a certain obliteration of the differences between fish length in older fish. As regards length distribution of females, modal values were clearly noticeable: $20,28,32$ and $40 \mathrm{~cm}$, corresponding to age groups III, IV, V and VIII.

Relationship between total fish length ( $\mathrm{L}$ ) and length of the longer otolith radius $(\mathbb{R})$.

Character of this dependence affected interpretation and method of the back calculation. Within fish length range $1.78-42.90 \mathrm{~cm}$, and age group range $0-\mathrm{IX}$, this dependence was expressed by the equation: $\mathrm{L}=0.2381+9.8076 \mathrm{R}, \mathrm{r}=0.9676$ (Fig. 3).

It can be concluded from this equation that zero otolith length corresponded to fish length $0.24 \mathrm{~cm}$. In view of the length range of the fish under study, this displacement in the coordinate system is negligible. Thus, Dahl-Lea method of the back calculation may

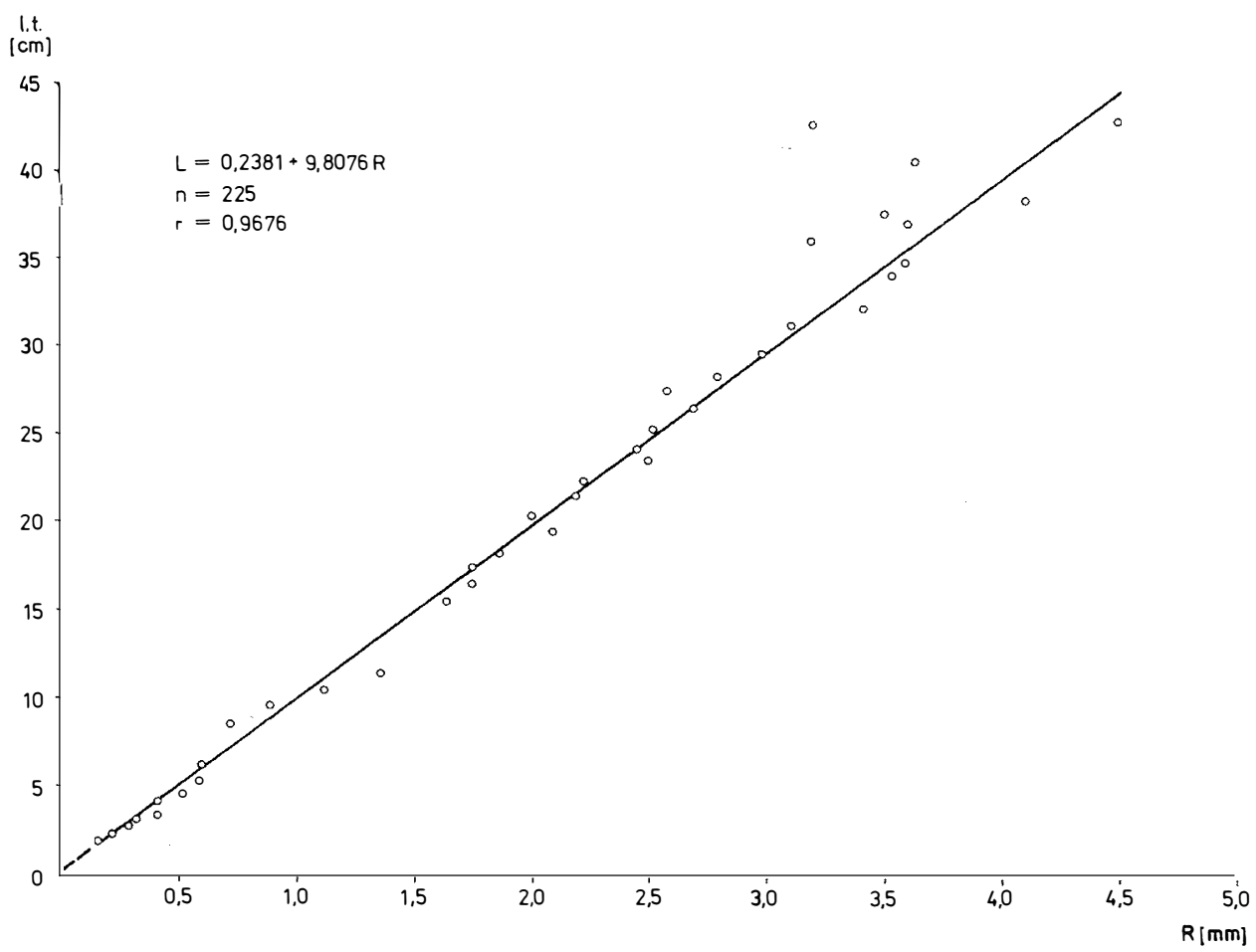

Fig. 3. Relationship between turbot total length [L] and longer otoliths radius $[R]$ 
safely be used. Similar dependence was found by Szlakowski (1985) for Psetta maxima juveniles (108 indiv., age groups 0 and I, length range 19.5-120.0 mm); $\mathbb{L}=1.2398+47.9551 \mathrm{~S}, \mathbb{r}=0.9974$, during an analysis of the relation between total fish length and otolith length ( $\mathrm{S}$ in $\mathrm{mm}$ ).

\section{Rate of growth in length}

Back calculation served to establish average fish length in consecutive years of life. This, in turn, was used to determine rate of growth in length and annual increments (Fig. 4). The data were also taken advantage of in calculating parameters of von Bertalanffy's equation and the 2 nd degree polynomial, so that theoretical models of Psetta maxima growth could have been worked out (Figs. 5 and 6, Tab. 1, 2 and 3), and parameters of these models could have been computed (Tab. 4).

Von Bertalanffy's equations for Psetta maxima in the Gulf of Pomerania are as follows:

males:

$$
\begin{aligned}
& \mathbb{L}_{\hat{\imath}}=33.4\left[1-e^{-0.347(\hat{\imath}-0.413)}\right] \\
& \text { females: } \\
& \mathbb{L}_{\hat{\imath}}=51.9\left[1-e^{-0.2003(\hat{\imath}-0.296)}\right]
\end{aligned}
$$

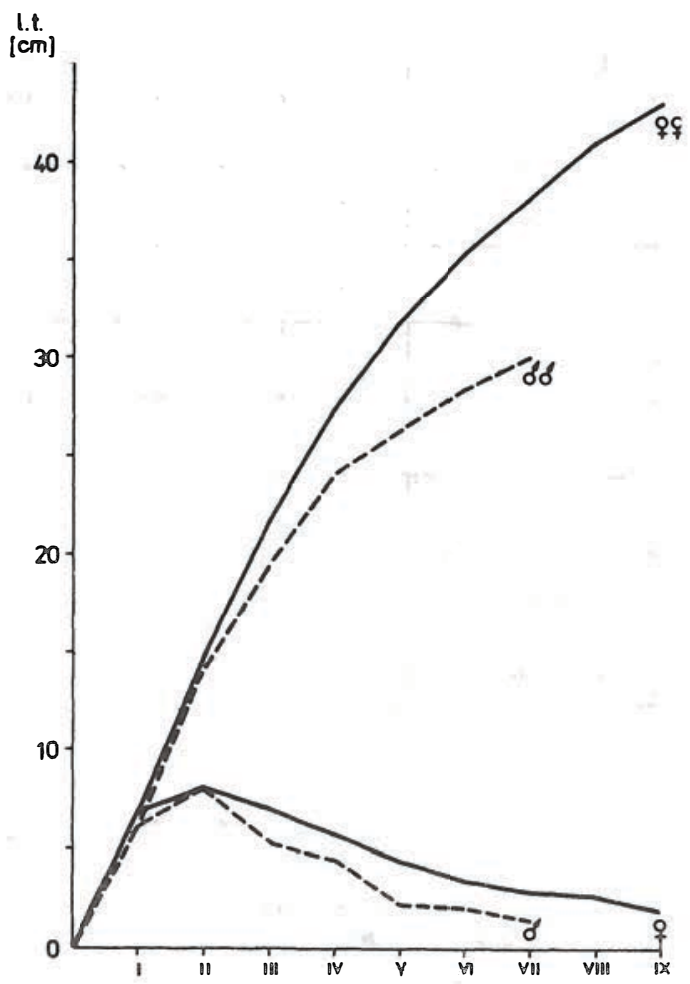

Maximum age, $t_{\max B}$ (in which the fish attain the length $\mathbb{L}_{\circ}$ 0.95), and the corresponding maximum length $\mathbb{L}_{\max B^{\prime}}$ are 9.1 years and $31.8 \mathrm{~cm}$ for males, and 15.3 years and $49.3 \mathrm{~cm}$ for females (Tab. 4).

Polynomials of the 2 nd order are as follows:

males: $\mathbb{L}_{t}=-1.515+8.856 \hat{t}-0.63 t^{2}$,

females: $\mathbb{L}_{\hat{t}}=-1.062+8.742 t-0.436 \mathrm{t}^{2}$

Maximum age, $t_{\max }$ (corresponding to function maximum in case of the polynomials), and the corresponding maximum length, $\mathbb{L}_{\max }$, are 7.0 years and $29.6 \mathrm{~cm}$ for males, and 10.0 years and $42.8 \mathrm{~cm}$ for females.

In the first two years of life, both males and females attain similar length; the differences do not exceed $1 \mathrm{~cm}$. Differentiation of growth takes place in the third year of life. Females are still characterized by high growth rate, while growth of males is 
Table 1

Rate of length growth of turbot males

[back calculations from otolishs]

\begin{tabular}{|c|c|c|c|c|c|c|c|c|}
\hline $\begin{array}{c}\text { Length of fish } \\
\text { [cm } \\
\text { Age group }\end{array}$ & $1_{1}$ & $1_{2}$ & $1_{3}$ & $1_{4}$ & $1_{5}$ & $1_{6}$ & $1_{7}$ & $\begin{array}{c}\text { No. of } \\
\text { fish }\end{array}$ \\
\hline I & 6.2 & & & & & & & 2 \\
\hline II & 7.0 & 14.5 & & & & & & 4 \\
\hline III & 6.1 & 14.3 & 19.5 & & & & & 74 \\
\hline IV & 6.5 & 14.6 & 20.3 & 24.0 & & & & 6 \\
\hline V & 6.3 & 14.0 & 20.0 & 24.1 & 26.4 & & & 8 \\
\hline VI & 6.0 & 14.5 & 20.0 & 24.2 & 26.6 & 28.4 & & 1 \\
\hline VII & 6.5 & 14.5 & 20.2 & 24.0 & 26.3 & 28.6 & 30.1 & 1 \\
\hline Mean lengths & 6.2 & 14.3 & 19.6 & 24.1 & 26.4 & 28.5 & 30.1 & 96 \\
\hline
\end{tabular}

Table 2

Rate of length grow th of turbot females

[back calculations from otoliths]

\begin{tabular}{|c|c|c|c|c|c|c|c|c|c|c|}
\hline $\begin{array}{c}\text { Length of fish } \\
\text { [cm] }\end{array}$ & $1_{1}$ & $1_{2}$ & $1_{3}$ & $1_{4}$ & $1_{5}$ & $1_{6}$ & $1_{7}$ & $1_{8}$ & $1_{9}$ & $\begin{array}{c}\text { No. of } \\
\text { fish }\end{array}$ \\
\hline III group & & & & & & & & & & \\
\hline IV & 6.7 & 14.7 & 22.8 & 27.0 & & & & & & 13 \\
\hline V & 6.9 & 14.6 & 22.4 & 27.6 & 32.0 & & & & & 3 \\
\hline VI & 7.6 & 15.0 & 22.6 & 27.6 & 31.6 & 35.4 & & & & 2 \\
\hline VII & 7.3 & 15.5 & 22.6 & 27.7 & 32.0 & 35.4 & 38.3 & & & 3 \\
\hline VIII & 6.9 & 14.8 & 22.2 & 27.8 & 31.9 & 35.3 & 38.2 & 40.9 & & 5 \\
\hline IX & 6.8 & 15.6 & 23.0 & 27.7 & 31.1 & 34.8 & 38.2 & 40.8 & 42.8 & 2 \\
\hline Mean lengths & 6.8 & 14.8 & 21.7 & 27.4 & 31.8 & 35.3 & 38.2 & 40.9 & 42.8 & 59 \\
\hline
\end{tabular}


Table 3

Comparison of rate of length growth of turbot males and females according to various methods

\begin{tabular}{|c|c|c|c|c|c|c|c|c|c|c|c|}
\hline $\begin{array}{l}\text { lengths } \\
(\mathrm{cm})\end{array}$ & & $l_{1}$ & $\mathrm{l}_{2}$ & $l_{3}$ & $1_{4}$ & $1_{5}$ & $1_{6}$ & $l_{7}$ & $1_{8}$ & $\mathrm{l}_{9}$ & ${ }^{1} 10$ \\
\hline \multirow{2}{*}{$\begin{array}{l}\text { Back } \\
\text { Calculations }\end{array}$} & $\delta$ & 6.2 & 14.3 & 19.6 & 24.1 & 26.4 & 28.5 & 30.1 & & & \\
\hline & $q$ & 6.8 & 14.8 & 21.7 & 27.4 & 31.8 & 35.3 & 38.2 & 40.9 & 42.8 & \\
\hline \multirow{2}{*}{$\begin{array}{l}\text { Length according to } \\
\text { Von Bertalanffy } \\
\text { equation }\end{array}$} & $\delta$ & 6.2 & 14.1 & 19.8 & 23.8 & 26.6 & 28.6 & 30.0 & 31.0 & 31.7 & 32.2 \\
\hline & & 6.8 & 15.0 & 21.7 & & 31.7 & & & & & 44.5 \\
\hline \multirow{2}{*}{$\begin{array}{l}\text { Length according to } \\
\text { Second-order } \\
\text { polynomial }\end{array}$} & ర & 6.7 & 13.7 & 19.4 & 23.8 & 27.0 & 28.9 & 29.6 & & & \\
\hline & q & 7.2 & 14.7 & 21.2 & 26.9 & 31.8 & 35.7 & 38.8 & 41.0 & 42.3 & 42.8 \\
\hline
\end{tabular}

Table 4

Comparison of von Bertalanffy equation and second - order polynomial parameters $\left[\mathrm{t}_{\operatorname{maxB}}, \mathrm{L}_{\operatorname{maxB}}\right.$ - calculated according to von Bertalanffy equation; $t_{\operatorname{maxW}}, \mathrm{L}_{\operatorname{maxW}}$, $\mathrm{V}_{\mathrm{L}}$ - according to second - order polynomial]

\begin{tabular}{|l|c|c|c|c|c|c|c|c|}
\hline & $\mathbf{K}$ & $\begin{array}{c}\mathrm{t}_{0} \\
{[\mathrm{yrs}]}\end{array}$ & $\begin{array}{c}\mathrm{L}_{00} \\
{[\mathrm{~cm}]}\end{array}$ & $\begin{array}{c}\mathrm{t}_{\operatorname{maxB}} \\
{[\mathrm{yrs}]}\end{array}$ & $\begin{array}{c}\mathrm{t}_{\operatorname{maxW}} \\
{[\mathrm{yrs}]}\end{array}$ & $\begin{array}{c}\mathrm{L}_{\operatorname{maxB}} \\
{[\mathrm{cm}]}\end{array}$ & $\begin{array}{c}\mathrm{L}_{\operatorname{maxW}} \\
{[\mathrm{cm}]}\end{array}$ & $\begin{array}{c}\mathrm{V}_{\mathbf{L}} \\
{[\mathrm{cm} / \mathrm{yr}]}\end{array}$ \\
\hline Males & 0.347 & 0.413 & 33.4 & 9.1 & 7.0 & 31.8 & 29.6 & 4.2 \\
\hline Females & 0.2003 & 0.296 & 51.9 & 15.3 & 10.0 & 49.3 & 42.8 & 4.3 \\
\hline
\end{tabular}

considerably inhibited. The differences in average length between males and females increases to $1.9 \mathrm{~cm}$ in the third year of life, and as many as $8.3 \mathrm{~cm}$ in the seventh (according to von Bertalanffy's equation). Average rate of growth in length, $\mathrm{V}_{\mathrm{L}}$, is practically identical fot both sexes, being $4.2 \mathrm{~cm} /$ year for males and $4.3 \mathrm{~cm} /$ year for females, but in case of males this value is applicable to the period $\mathrm{t}_{\mathrm{maxW}}=7$ years, and in case of females to $t_{\text {maxW }}=10$ years.

Average length in the third year of life of both males and females (established from back calculation) for the most numerous (and thus most representative) age group III deviated from the average values obtained for the third year of life in other age groups 


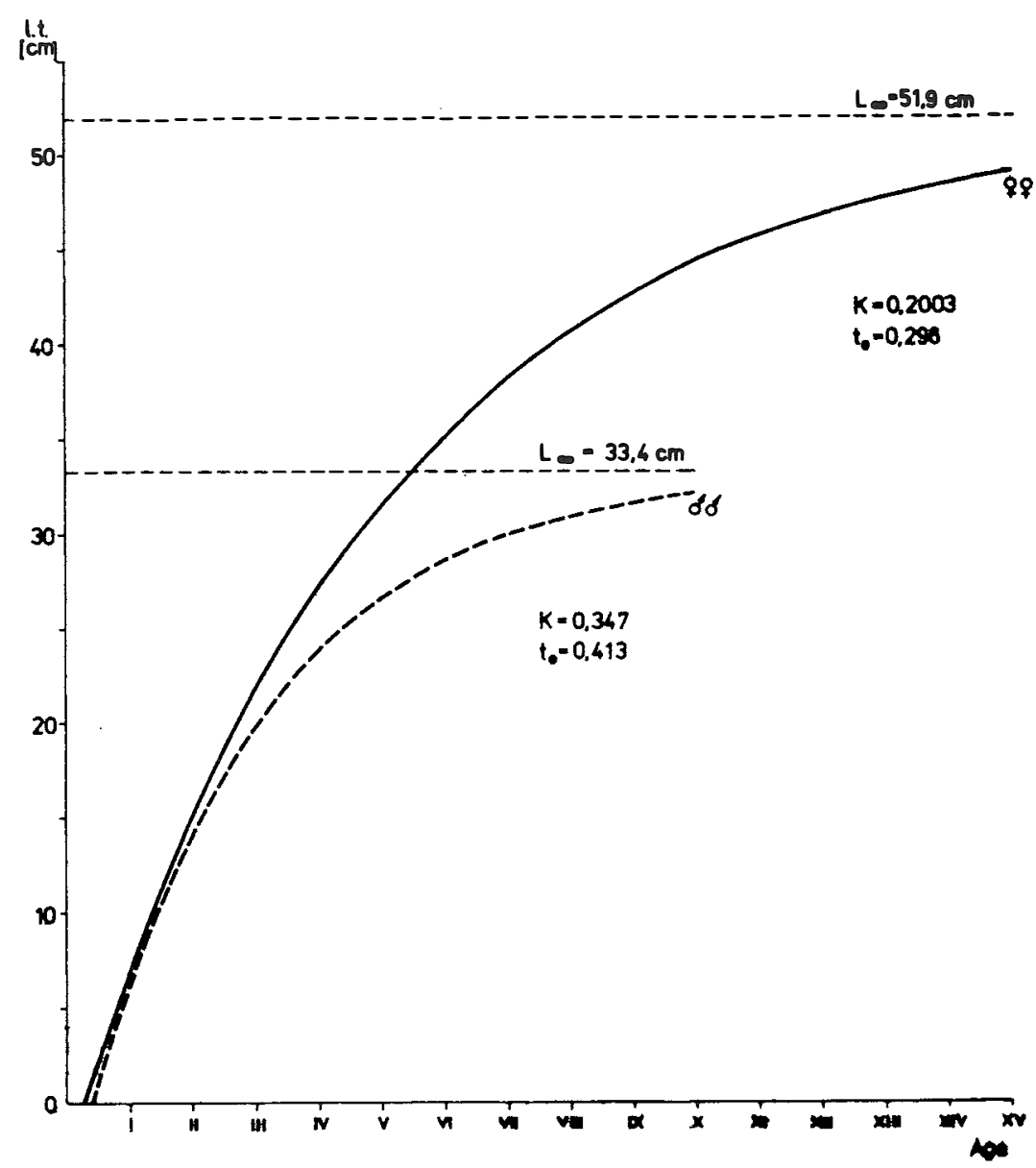

Fig. 5. Length growth curves of turbot males and females according to von Bertalanffy equation.

(Tab. 1 and 2). This difference was very small for males (maximum $0.8 \mathrm{~cm}$ ), but fairly significant for females, reaching $2.2 \mathrm{~cm}$. Since these age gorups predominated in the samples, calculation of average length in the third year of life for both sexes was somehow biased. Assuming normal length distribution in particular age groups, and taking into account that age group III predominated the sample of males, representing $77.1 \%$ of all males under study, the difference of about $0.6 \mathrm{~cm}$ in relation to other age groups seems natural.

As regards females, age group III also predominated, embracing $52.5 \%$ of the sample. Length range within this group was fairly large: $17-23 \mathrm{~cm}$. Length difference in the third year of life amounted on the average to $1.8 \mathrm{~cm}$ in relation to other age groups. This difference was probably caused by considerable variation of length in the age group III. As a result of these variations, average length was underestimated. Materials for this study 


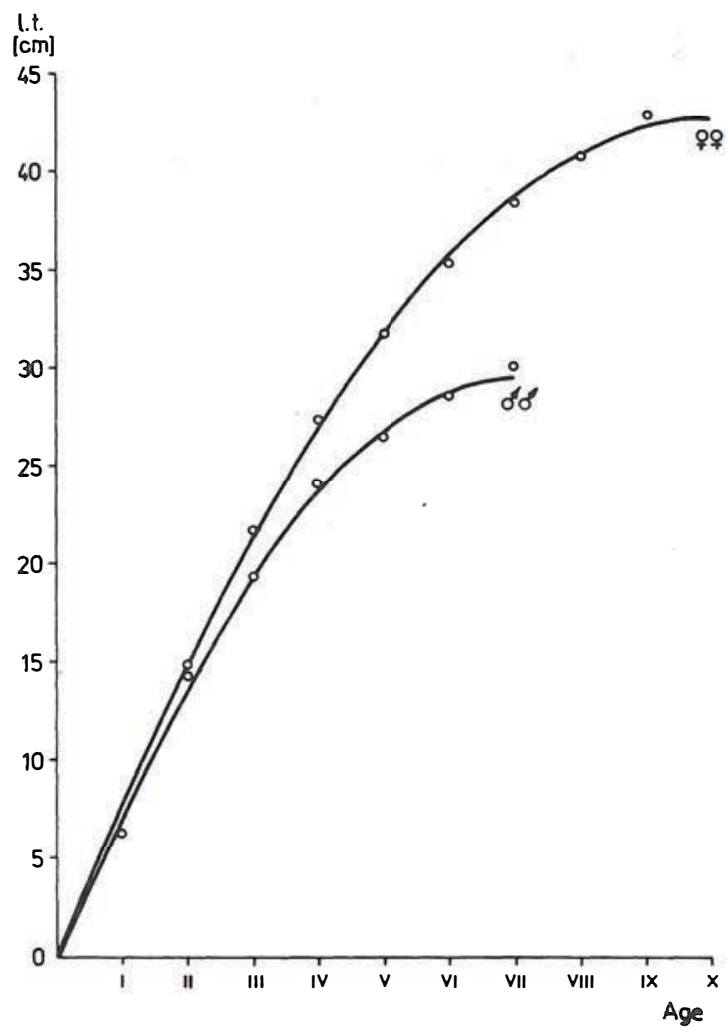

Fig. 6. Length growth curves of turbot males and females according to second - order polynomial.

were collected since March till May. Otoliths of the fish caught in March and April had glassy hyaline zone at their margin, whereas otoliths of the fish caught in May had already developed a new growth: opaque zone. There was almost a month gap between samples collected in April and May. Consequently, fish caught in May (third decade) were able to complete annual growth increment and initiate new season, contrary to the fishes caught earlier. This might have resulted in a difference of length assessment of $1-2 \mathrm{~cm}$.

\section{Rate of growth in weight}

Average weight in particular length classes was similar for both sexes. Notwithstanding this, considerable differences in length between males and females were reflected in fish weight. Dependence between total fish length and weight was calculated separately for males and females (Fig. 7). The equation for males is:

$$
\begin{aligned}
& W=0.0167 L^{3.0223} \quad \text { and for females: } \\
& W=0.0099 L^{3.1783}
\end{aligned}
$$




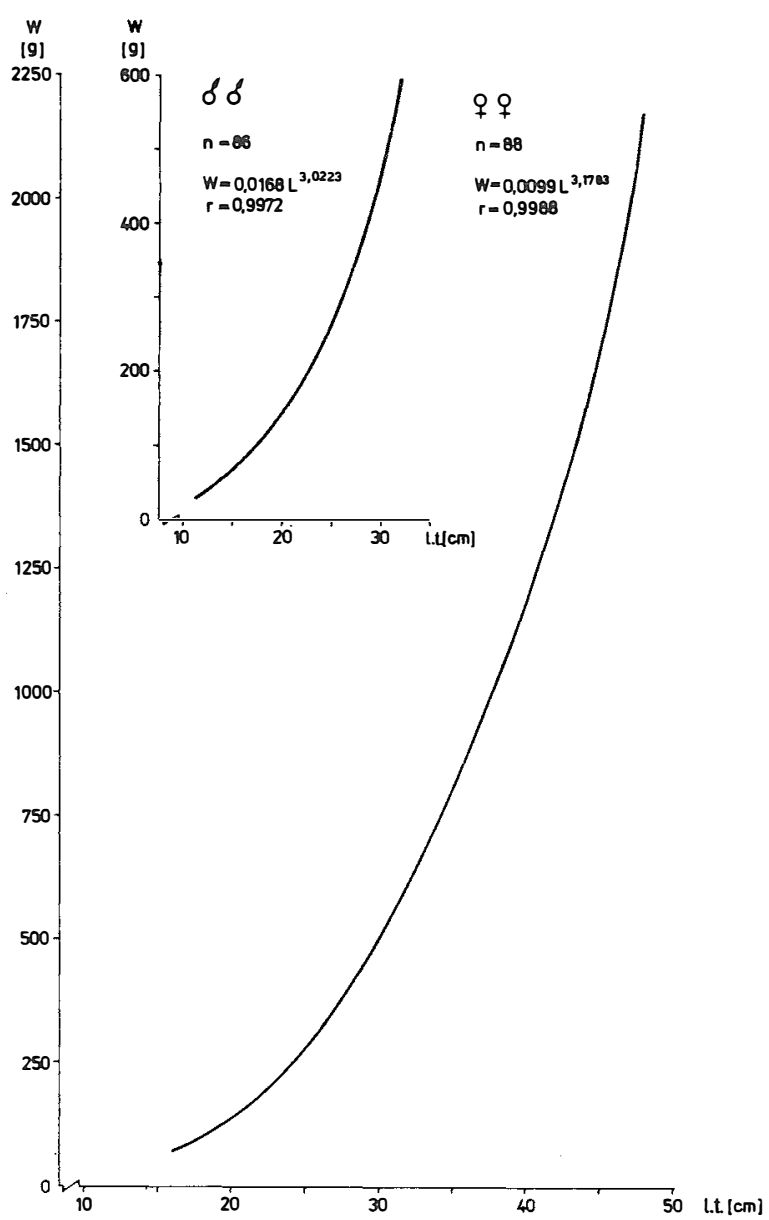

Fig. 7. Total length - total weight relationships for turbot males and females

Using $L_{\infty}$ value for males and females in these equations, corresponding $W_{\infty}$ values were obtained ( $\mathrm{W}_{\infty}=676.9 \mathrm{~g}$ for males and $2798.7 \mathrm{~g}$ for females); which were then used to calculate growth in weight of the fish in consecutive years of life. Modified von Bertalanffy's equation (Fig. 8, Tab. 5) was used:

for males $\quad W_{t}=676.9\left[1-\mathrm{e}^{-0.3 \dot{4} 7(t-0.413)}\right]^{3.0223}$

for females: $\quad W_{t}=2798.7\left[1-\mathrm{e}^{-0.2003(t-0.296)}\right]^{3.1783}$

Similarly as length, growth in weight was the same for males and females in the first years of life. It began to differentiate in the third year. In the next years, females became much heavier than males of the same age. Weight difference amounted to $36 \mathrm{~g}$ in the third 
Rate of weight growth of turbot males and females according to modified von Bertalanffy equation - A and third-order polynomial - B

\begin{tabular}{|c|c|c|c|c|}
\hline \multirow{2}{*}{$\begin{array}{l}\text { Weight } \\
\text { at age } n \\
\left(w_{n}\right) \text { in } g\end{array}$} & \multicolumn{2}{|c|}{$\mathbf{A}$} & \multicolumn{2}{|c|}{ B } \\
\hline & 0 & $q$ & $0^{*}$ & q \\
\hline $\mathrm{w}_{1}$ & 4.1 & 4.4 & 6.2 & 14.4 \\
\hline $\mathrm{w}_{2} 1$ & 50.4 & 54.2 & 43.6 & 38.9 \\
\hline $\mathrm{w}_{3}$ & 139.2 & 175.2 & 131.7 & 163.2 \\
\hline$w_{4}$ & 242.4 & 358.4 & 244.4 & 360.1 \\
\hline $\mathrm{w}_{5}$ & 340.2 & 582.3 & 355.7 & 602.4 \\
\hline $\mathrm{w}_{6}$ & 423.3 & 825.3 & 439.3 & 862.8 \\
\hline $\mathrm{w}_{7}$ & 489.5 & 1069.7 & 469.4 & 1114.3 \\
\hline $\mathrm{w}_{8}$ & 540.3 & 1303.4 & - & 1329.6 \\
\hline $\mathrm{w}_{9}$ & 578.2 & 1510.0 & - & 1481.4 \\
\hline $\mathrm{w}_{10}$ & 606.1 & 1712.7 & - & 1542.8 \\
\hline
\end{tabular}

Table 6

Comparison of modified von Bertalanffy equation and third order polynomial parameters $t_{\max B}, W_{\max B}, t_{p B}, W_{p B}$ - calculated according to modified von Bertalanffy equation; $t_{\max }, W_{\max }, t_{p W}, V_{W}$ - according $t$ third order polynomial. $t_{p}, W_{p}-$ coordinates of point of inflection

\begin{tabular}{|c|c|c|}
\hline Parameter & Males & Females \\
\hline $\mathrm{K}$ & 0.347 & 0.2003 \\
$\mathrm{t}_{\mathrm{o}}(\mathrm{yrs})$ & 0.413 & 0.296 \\
$\mathrm{~W}_{\infty}(\mathrm{g})$ & 676.9 & 2798.7 \\
$\mathrm{t}_{\operatorname{maxB}}(\mathrm{yrs})$ & 9.1 & 15.3 \\
$\mathrm{~W}_{\operatorname{maxB}}(\mathrm{g})$ & 581.4 & 2381.5 \\
$\mathrm{t}_{\mathrm{pB}}(\mathrm{yrs})$ & 3.6 & 6.1 \\
$\mathrm{~W}_{\mathrm{pB}}(\mathrm{g})$ & 200.6 & 829.3 \\
$\mathrm{t}_{\operatorname{maxW}}(\mathrm{yrs})$ & 6.9 & 10.1 \\
$\mathrm{~W}_{\operatorname{maxW}}(\mathrm{g})$ & 469.6 & 1543.0 \\
$\mathrm{t}_{\mathrm{pW}}(\mathrm{yrs})$ & 3.9 & 5.7 \\
$\mathrm{~W}_{\mathrm{pW}}(\dot{\mathrm{g}})$ & 232.8 & 784.4 \\
$\mathrm{v}_{\mathrm{W}}(\mathrm{g} / \mathrm{yr})$ & 68 & 153 \\
\hline
\end{tabular}




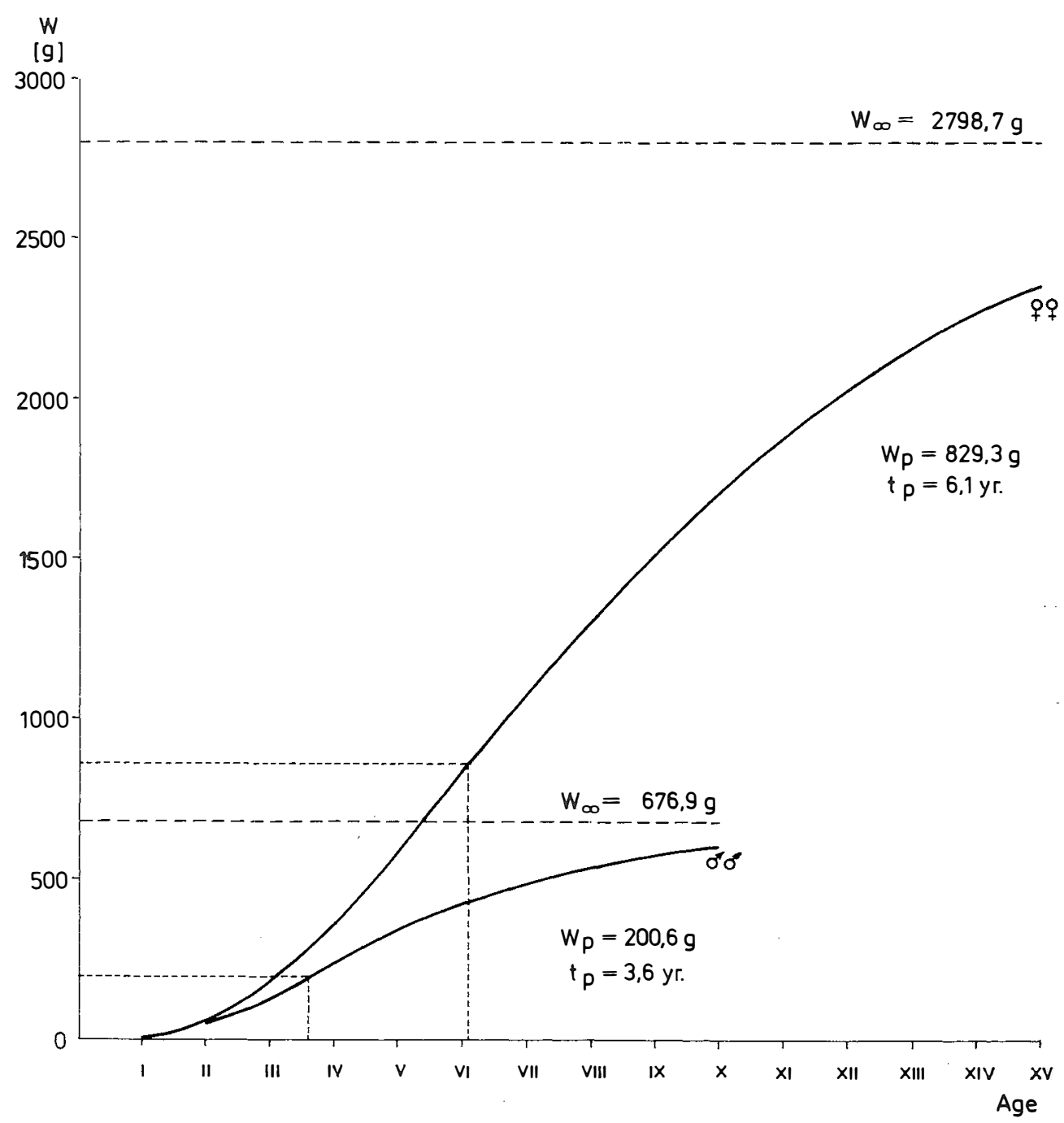

Fig. 8. Weight growth curves for turbot males and females. according to modified von Bertalanffy equation

$\left[w_{p}, t-p o i n t\right.$ of inflection coordinates].

year, but reached $1106.6 \mathrm{~g}$ in the tenth year. Males were characterized by increasing growth increments till 3.6 year (maximum of the curve illustrating growth in weight). Afterwards, increments in weight gradually decreased. Maximum of the growth curve for females was in 6.1 years, but increments were high (thought decreasing) even beyond this maximum.

Growth in weight was also described with the polynomial of the 3rd order (Fig. 9) as follows: 
For males: $\quad \mathrm{W}_{\mathrm{t}}=45.525-86.369 \mathrm{t}+51.404 \mathrm{t}^{2}-4.345 \mathrm{t}^{3}$,

for females: $\quad \mathrm{w}_{\mathrm{t}}=116.816-174.967 \mathrm{t}+77.076 \mathrm{t}^{2}-4.532 \mathrm{t}^{3}$

The results were similar to those obtained with von Bertalanffy's equations. Some differences were related only to weight increments in the first two years of life (Tab. 5).

An index characterizing average rate of weight increments, $\mathrm{V}_{\mathrm{w}}$, also pointed to the differences between growth rate of males and females. Value of this index was $68 \mathrm{~g} / \mathrm{year}$ for males and $153 \mathrm{f} /$ year for females, at maximal age, $\mathrm{t}_{\operatorname{maxW}}, 6.9$ years for males and 10.1 years for females (Tab.6). The results were thus different than in case of length, when $\mathrm{V}_{\mathrm{L}}$ index showed no differences in the rate of growth.

\section{DISCUSSION ADN CONCLUSIONS}

Otoliths are widely used in back calculation and age determination of Pleuronectiformes. Age of Psetta maxima was determined from the otoliths by Cięglewicz et al. (1969), Rae and Develin (1972) and Jones (1974). Kyle (cit. after Jones 1974) used operculum bones instead.

Psetta maxima is characterized by good growth in length for the first three years of life, especially in the second year. Sexual dimorphism is expressed in this species by differences in length, becoming noticrable since the third year of life, when growth of males becomes inhibited. This takes place in females in the fourth year of life, but to a much smaller degree. Growth in weight continues to be good for some time; its inhibition takes place in 3.6 year in males and 6.1 year in females, although weight increments of females remain quite high.

\section{Table 7}

Comparison of von Bertalanffy equation parameters

for turbot from Gdansk and Pomeranian Bays

\begin{tabular}{|c|c|c|c|c|}
\hline \multirow{2}{*}{} & \multicolumn{2}{|c|}{$\begin{array}{c}\text { Gdansk Bay } \\
\text { Cicglewicz et al. [1969] }\end{array}$} & \multicolumn{2}{c|}{$\begin{array}{c}\text { Pomeranian Bay } \\
\text { author's data }\end{array}$} \\
\hline \multirow{2}{*}{$\mathrm{L}_{00}[\mathrm{~cm}]$} & males & females & males & females \\
\cline { 2 - 5 } & 32.9 & 51.3 & 33.4 & 51.9 \\
\hline $\mathrm{W}_{00}[\mathrm{~kg}]$ & 0.682 & 2.528 & 0.677 & 2.799 \\
\hline $\mathrm{K}$ & 0.381 & 0.215 & 0.347 & 0.2003 \\
\hline $\mathrm{t}_{0}[\mathrm{yrs}]$ & 0.450 & 0.350 & 0.413 & 0.296 \\
\hline
\end{tabular}




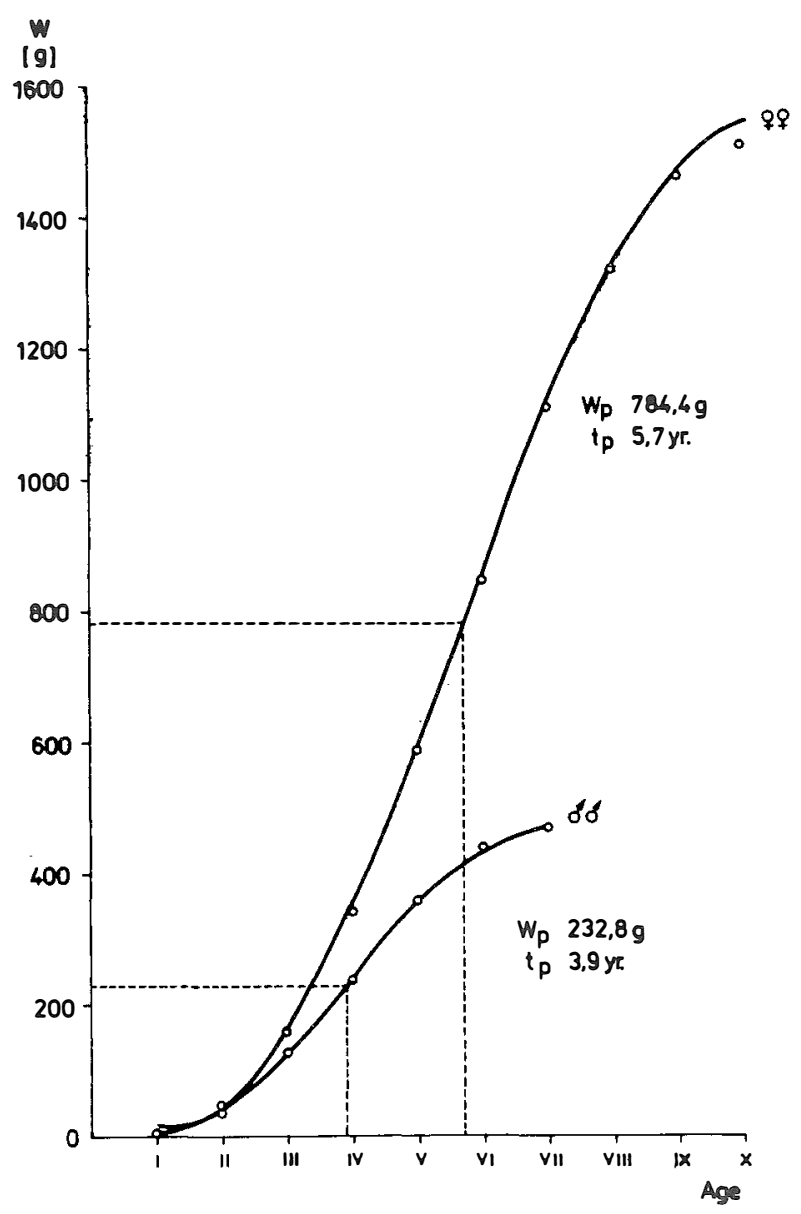

Fig. 9. Weight grow th curves for turbot males and females according to third - order polynomial $\left[W_{\hat{p}}, t_{p}-\right.$ point of inflection coordinates].

Cięglewicz et al. (1969) studied growth rate of Psetta maxima in the Gulf of Gdanisk. Comparison of the parameters of von Bertalanffy's equation given by these authors with those obtained for Psetita maxima in the Gulf of Gdańsk showed that there were no differences between the two fish populations (Tab. 7). On the other hand, growth rate and maximal size attained by Psetta maxima in the Baltic Sea differed from those attained by this fish in the North Sea. For instance, Jones (1974) stated that $\mathbb{L}_{\infty}$ amounted to $49.2 \mathrm{~cm}$ for males and $64.8 \mathrm{~cm}$ for females. Differentiation of growth between fish in the Baltic and North Sea took place in the second year of life; sizes attained in the first year were comparable (Szlakowski 1985). 
Growth in length and weight of Psetta maxima was described equally well by von Bertalanffy's equations and polynomials of the 2 nd and 3rd degree. Curves obtained with the two methods fit well the empirical data on length and properly model the weight increments. Maxima of both curves approximating weight increments have similar coordinates. There are, however, differences in the parameters estimating maximal age and maximal fish size in the population under study $\left(\mathrm{t}_{\max }, \mathrm{L}_{\max }, \mathrm{W}_{\max }\right)$, both as regards growth in length and growth in weight. These differences resulted from the assumptions referring to the growth models as such. Asymptotic model of von Bertalanffy assumes indefinite fish growth, so the equation parameters are higher. Model by Szypu ła, based on polynomials, assumes growth inhibition (limits), so that maximal values of the parameters are only slightly higher than the highest empirical values. In case of the population under study, parameters obtained from von Bertalanffy's equation seem more adequate.

\section{REFERENCES}

Balicki A., Bielecki Jo, 1980: Metody statystyczne w rybołówstwie. [Statistical methods in fishery]. (In Polish). Materiały MIR, ser. E, nr 41: 221-251.

Cięglewicz W., B. Draganik, Cz. Żukowski, 1969: Characteristic of growth of flounder (Platichthys flesus L.) and turbot (Scophthalmus maximum L.) by means of the v. Bertalanffy's equation. (In Polish with English summary). Prace MIR, 15, ser. A: 121-132.

Draganik B., ZZ. Reiman, 1979: Flounder, plaice and turbot fished along the Polish coast in 1978. ICES, C.M., J: 17. Baltic Fish Comm.

FAO Fish. Circular No. 736, 1981: Methods of collecting and analysing size and age data for fish stock assessmient. Rome.

Fesołowicz W., J. Wiktor, 1959: Płasiugi w polskich połowach przybrzeżnych w Zatoce Pomorskiej. [Flatfishes in Polish coastal catches in the Gulf of Pomerania] (In Polish). Prace MIR, nr 10/A: 385-399.

ICES 1982: Bulletin Statistique des Peches Maritimes. Copenhagen, vol. 65.

Jones A., $\downarrow 1$ 1974: Sexual maturity, fecundity and growth of the turbot, Scophthalmus maximus (L.). J. Mar. Biol. ASS. UK, 54: 109-125.

Pauly D., 1980: A selection of simple methods for the assessment of tropical fish stocks. FAO Fish. Circ. 729: 41 pp, Rome.

Pollard J.H., 1982: A handbook of numerical statistical techniques. (In Rüssian, transl. from English), Moskwa, Finansy i Statistika: 260-326.

Rae B.B., S.D.E. Devlin, 1972. The turbot, its fishery, and biology in Scottish Area. Mar. Res., 1: 27 pp.

Ricker W.E., 1983. Growth rates and models. In: Fish physiology, vol. 8. Hoar S., Randall D.J., Brett J.B. (eds) (In Russian, transl. from English). Moskwa, Liegkaja i piszczewaja promyszlennost.

Szlakowslki J., 1985: Badania nad biologią skarpia, Psetta maxima (L.) z Zatoki Pomorskiej. (Studies on the biology of Psetta mœima (L.) from the Gulf of Pomerania]. (M.Sc. degree paper). AR Szczecin: 91 pp. (in Polish).

Szypula J., 1977: Application of second and third order polynomials to fish growth description. (In Polish with English. summary). AR Szczecin, Rozprawy, 52: 74 pp.

Taylor C.C., 1962: Growth equations with metabolic parameters. J. Cons. int. Explor. Mer., 27, 3: 270-286.

Translated: Dr M. Bnińska 
Jacek Szlakowski

WZROST SKARPIA PSETTA MAXIMA (LINNAEUS, 1758) Z ZATOKI POMORSKIEJ

\section{STRESZCZENIE}

Materiał pochodzący z przybrzeżnych łowisk Zatoki Pomorskiej (Rys. 1) zebrano 'wokresie od' marca do maja 1984. W połowach występowały samce o długościach od 8 do $32 \mathrm{~cm} \mathrm{z} \mathrm{grup} \mathrm{wieku} \mathrm{od}$ I do VII oraz samice o długościach od 16 do $48 \mathrm{~cm}$ z grup wieku od III do IX i starsze, których wieku nie oznaczono (rys. 2). Ustalono, że zależność pomiędzy długością całkowitą ryb (L.), a długością dłuższego promienia otolitu $(\mathrm{R})$ jest prostoliniowa i wyraża się równaniem: $\mathrm{L}=0.2381+9.8076 \mathrm{R}$ (Rys. 3), co umożliwia dokonanie odczytów wstecznych metodą DahłLea. Zróżnicowanie wzrostu samców i samic następuje w trzecim roku życia (Rys. 4, Tab. 1 i 2). Wzrost długości opisano przy pomocy równania von Bertalanffy'ego i wielomianu 2-go stopnia (Rys. 5 i 6, Tab. 3 i 4). Parametry równania von Bartelanffy'ego są następujące:

dla samców: $\mathrm{L}_{\infty}=33.4 \mathrm{~cm} ; \mathrm{K}=0,347 ; \mathrm{t}_{0}=0.413$ roku,

dla samic: $\mathrm{L}_{\infty}=51.9 \mathrm{~cm} ; \mathrm{K}=0,2003 ; \mathrm{t}_{\mathrm{o}}=0.296$ roku.

Równania wielomianów mają postać:

dla samców: $\mathrm{L}_{\mathrm{t}}=-1.515+8.856 \mathrm{t}-0.63 \mathrm{t}^{2}$,

dla samic: $\mathrm{L}_{\mathrm{t}}=-1.062+8.742 \mathrm{t}-0.436 \mathrm{t}^{2}$.

Zależność pomiędzy długością i masą ciała skarpia wyraża się wzorem: $\mathrm{W}=0.0168 \mathrm{~L}^{3.0223} \mathrm{dla}$ samców i W $=0.0099 \mathrm{~L}^{3.1783}$ dla samic (Rys. 7). Wyznaczony na ich podstawie parametr zmodyfikowanego równania von Bartalanffy'ego wzrostu masy $\mathrm{W}_{\infty}$ wynosi dla samców $676.9 \mathrm{~g}$ a dla samic 2798.7 g (Rys. 8, tab. 5 i 6). Wzrost masy opisano także przy pomocy wielomianu 3-go stopnia (Rys. 9) otrzymując równanie:

dla samców: $\mathrm{W}_{\mathrm{t}}=45.525-86.369 \mathrm{t}+51.404 \mathrm{t}^{2}-4.345 \mathrm{t}^{3}$

dla samic: $\mathrm{W}_{\mathrm{t}}=116.816-174.967 \mathrm{t}+77.076 \mathrm{t}^{2}-4.532 \mathrm{t}^{3}$.

Obydwa modele wzrostu dobrze pasują do danych empirycznych, istnieją natomiast różnice w wielkościach parametrów szacujących maksymalne rozmiary ryb (Tab. 4 i 6). Nie stwierdzono różnic w tem pie wzrostu skarpia z Zatoki Pomorskiej i Zatoki Gdańskiej (Tab. 7).

Author's address:

Received: 1988.09 .20

Mgr Jacek Szlakowski

Instytut Oceanografii

Rybackiej i Ochrony Morza

ul. Kazimierza Królewicza 5

71-550 Szczecin

Polska (Poland) 